\author{
ACTA MYCOLOGICA \\ Vol. 47 (1): 11-19 \\ 2012
}

\title{
Phyllosphere mycobiota on garden pond plants
}

\author{
MARIA KOWALIK \\ Department of Plant Protection, Hugo Kołłątaj University of Agriculture in Kraków \\ 29 Listopada 54, PL-31-425 Kraków, m.kowalik@ogr.ur.krakow.pl
}

Kowalik M.: Phyllosphere mycobiota on garden ponds plants. Acta Mycol. 47 (1): 11-19, 2012.

Investigations were conducted on calamus, common cattail, soft rush, yellow iris and white water lily plants in twenty ponds in Malopolska and Podkarpacie Regions. Mycobiota existing in the phyllosphere caused discolouring and necroses of leaves and shoots. 88 species of mycobiota were identified and isolated from the diseased tissues. Dominant were Alternaria alternata, Epicoccum nigrum and Isaria farinosa. Fungi of genera: Aspergillus, Botrytis, Chaetomium, Cladosporium, Fusarium, Ilyonectria, Mortierella, Mucor, Penicillium, Phialophora, Phoma, Pleustomophora, Sordaria, Trichoderma and Umbelopsis were also numerous. The monophagous and the polyphagous were identified.

Key words: garden pond, water plants, phyllosphere, fungi, chromistan fungi, plant diseases

\section{INTRODUCTION}

Garden pond is a specific system functioning on the border of water and land ecosystem. Plant phyllosphere is a natural place of mycobiota existence. In a pond environment mycobiota pressure on various water plant species is heightened, which results in the occurrence of disease symptoms.

The problems of water plants' health state, as results from the literature of the subject, has been still a rarely addressed issue, therefore presented investigations aimed at determining the species composition of the mycobiota settling the phyllosphere of ponds and causing diseases visible as colour changes and necrosis.

Presented work is a recapitulation of research results showing taxonomic and species diversity of the mycobiota existing in the phyllosphere of five plants: calamus, common cattail, soft rush, yellow iris and white water lily - invariable components of pond ecosystem (Kowalik, Maik 2010; Kowalik 2011a, b; Kowalik, Cwynar 2011; Kowalik 2012). 


\section{MATERIALS AND METHODS}

Field investigations were conducted during four vegetation seasons (2006, 20082010 ) in twenty ponds situated in house gardens in the Malopolska and Podkarpacie Regions. The investigations covered fourty plants from each species: calamus Acorus calamus L., common cattail Typha latifolia L., soft rush Juncus effusus L., yellow iris Iris pseudoacorus L. and white water lily Nymphaea alba L. Each year, five observation were carried out from April to October at four-six-weekly long intervals. Mycobiota were determined on the basis of etiological symptoms and microscopic analyses of mycelium, sporodochia, pycnidia, conidophores and conidia forming on diseased plants. 3200 infected fragments of necrotic plant tissues, including 600 fragments of calamus, soft rush and common cattail, each and 700 fragments of yellow iris and white water lily, each were collected for mycological analyses. Isolation and culturing of mycobiota were conducted using the standard methods practised in mycology. Mycobiota were classified to appropriate species using mycological keys: Booth (1971); Batko (1975); Domsch et al. (1980), Sutton (1980); Ho (1981); Ellis and Ellis (1987); Ramirez (1982); Sivenesan (1984).

\section{RESULTS}

In result of mycological analysis of the diseased tissues 2675 colonies of Fungi and fungi-like organisms Chromista were obtained, which belong to the following genera: Alternaria, Aspergillus, Botrytis, Chaetomium, Cladosporium, Davidiella, Drechslera, Epicoccum, Fusarium, Humicola, Ilyonectria, Isaria, Khuskia, Mortierella, Mucor, Penicillium, Phaeosphaeria, Phialophora, Phoma, Phyllosticta, Phytophthora, Rhizopus, Sordaria, Trichoderma, Umbelopsis and other (Tab. 1).

The mycobiota were represented by 88 species, which evidences species diversity in pond phyllosphere. The least number of species -27 settled calamus and the highest -43 common cattail. 37 were isolated from yellow iris tissues, 34 from soft rush, whereas 40 fungi species and 2 species of fungus-like organisms were isolated from white water lily.

The following were prevailing in the identified mycobiota community: Alternaria alternata constituting $33.23 \%$ of the whole community, Epicoccum nigrum $-10.24 \%$ and Isaria farinosa $-9.35 \%$. In the influent group (making up from 1 to $5 \%$ of the mycobiota community) identified were: Aspergillus niger f. niger, Botrytis cinerea, Chaetomium globosum, Cladosporium cladosporioides, Ilyonectria radicicola, Mortierella alpina, Mucor hiemalis, Penicillium aurantiogriseum, P. expansum, P. hirsutum var. hirsutum, P. verrucosum, Phoma medicaginis var. medicaginis, Pleustomophora richardsiae, Sordaria fimicola and Umbelopsis isabellina.

Polyphagous species, such as: $A$. alternata, $A$. niger. f. niger, E. nigrum, Fusarium poae, I. farinosa, M. alpina, S. fimicola and $U$. isabellina were identified among fungi existing in water plant phyllosphere. These fungi were settling necrotic tissues of all five plant species. B. cinerea, Ch. globosum, C. cladosporioides, $P$. aurantiogriseum, $P$. 
expansum, P. verrucosum, Phialophora cyclaminis, Ph. medicaginis var. medicaginis, Pleustomophora richardsiae and Rhizopus stolonifer existed on four plant species in ponds.

The monophagous were less numerous: Ascochyta acori was isolated from calamus, Phaeosphaeria eustoma (syn. Leptosphaeria typhae), Ph. typharum (syn. L. typharum) and Periconia typhicola from common cattail, whereas Physalospora scirpi (syn. Arthrinium curvatum v. minus), Phaeosphaeria juncina (syn. Leptosphaeria juncina), Morenoina paludosa, Paraphaeosphaeria michotii and Septoriella junci from soft rush.

Phytophthora citricola and Ph. undulata chromistan fungi were isolated from diseased petioles of white water lily.

Disease symptoms were visible on pond plants in all years of the investigations.

Broad spots, yellow in colour visible on calamus in May and June were located in top leaf parts, in the late summer season the colour changed to brownish-brown. The border of spots was changing colour from yellow through reddish to light brown. The spots were situated all over the leaf surface. Another symptom were narrow spindleshaped brown smudges and small, round dots with red-russet rim located along the vein. Tissue in places of the spot underwent necrosis and the heaviest intensity of necroses occurred in October. The following were most frequently isolated from the diseased tissues: A. alternata, I. farinosa, E. nigrum, B. cinerea and $A$. niger $\mathrm{f}$. niger.

Common cattail plants revealed first disease symptoms in May, visible as yellowish discolorations on top and base of leaves. In September the symptoms were visible on the surface of leaf blades as brown-red spots and smudges. By the end of vegetation necrotic spots covered the whole leaf blade area. Beside A. alternata, $I$. farinosa and $E$. nigrum, the most numerous fungi isolated from the necrotized tissues included $P$. expansum, $S$. fimicola and $P$. richardsiae.

The first symptoms of leaf spot disease were visible on soft rush in April as delicate chlorotic discolourings in leaf top parts. With time the leaves were yellowing and browning. Streaks of chlorotic tissue changing its colour to brown-black were noticeable on stems. These symptoms sometimes led to dieback of plant clusters in a pond. The species dominant on necrotised soft rush tissues were also A. alternata, I. farinosa and E. nigrum, B. cinerea, M. alpina and $S$. fimicola were numerous, too.

Disease symptoms and their exacerbation on yellow iris leaves were diversified in individual vegetation periods. Generally, first disease symptoms were observed in May and the greatest intensification occurred in September or October. Small elongated or oval yellowish spots were visible on leaf blade, which in time changed their colour to orange or brown. The spots were surrounded by a clear reddish or brown rim. Initially top leaf parts were dying back, whereas by the end of vegetation a full necrosis of leaf blades occurred. Spots and necrosis of yellow iris leaves were most frequently caused by: A. alternata, E. nigrum, I. farinosa, Ph. medicaginis var. medicaginis and Phyllosticta pseudoacori.

Leaf spot diseases, called brown leaf spot disease was visible on white water lily every year and in all ponds. The symptoms of disease, visible as tiny chlorotic discolourings of leaf blade, appeared in May. The symptoms were intensifying gradually and by the end of vegetation brown spots surrounded with yellowish or reddish rim covered a considerable part of leaf. Necrotic tissue was covered by a coating of a concentrically zoned mycelium. The tissue was crumbled and leaf perforation 
Table1

Mycobiota isolated from affected tissues of garden pond plants

\begin{tabular}{|c|c|c|c|c|c|c|c|}
\hline Fungus & 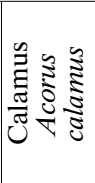 & 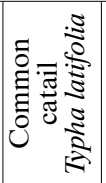 & 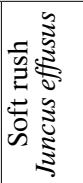 & 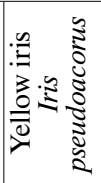 & 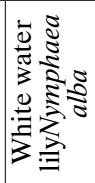 & 茜 & 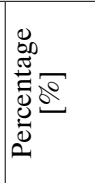 \\
\hline Alternaria alternata (Fr.) Keissl. & 277 & 183 & 110 & 215 & 104 & 889 & 33.23 \\
\hline Arthrinium sphaerospermum Fuckel & & 1 & & & & 1 & 0.04 \\
\hline Arthrinium sporophleum Kunze & & 5 & & & & 5 & 0.19 \\
\hline Arthrinium urticae M. B. Ellis & & 1 & & & & 1 & 0.04 \\
\hline Arthroderma tuberculatum Kuehn & & & 1 & & & 1 & 0.04 \\
\hline Ascochyta acori Oudem. & 3 & & & & & 3 & 0.11 \\
\hline Aspergillus alutaceus Berk. et M. A. Curtis & & & 1 & & & 1 & 0.04 \\
\hline $\begin{array}{l}\text { Aspergillus nidulans (Eidam) G. Winter } \\
\text { var. nidulans }\end{array}$ & & & & 5 & & 5 & 0.19 \\
\hline Aspergillus niger f. niger Tiegh. & 20 & 16 & 9 & 2 & 7 & 54 & 2.02 \\
\hline Aspergillus versicolor (Vuill.) Tirab. & & 6 & & 7 & 8 & 21 & 0.79 \\
\hline $\begin{array}{l}\text { Boeremia exigua var. exigua (Desm.) } \\
\text { Aveskamp, Gruyter et Varkley }\end{array}$ & & 1 & & 1 & & 2 & 0.07 \\
\hline $\begin{array}{l}\text { Boeremia hedericola (Durieu et Mont.) } \\
\text { Aveskamp, Gruyter et Verkley }\end{array}$ & 1 & 6 & & & & 7 & 0.26 \\
\hline Botryotinia convoluta (Drayton) Whetzel & & & & 6 & & 6 & 0.22 \\
\hline Botrytis cinerea Pers. & 23 & & 22 & 10 & 2 & 57 & 2.13 \\
\hline Chaetomium cochlioides Palliser & & & 1 & 3 & & 4 & 0.15 \\
\hline Chaetomium elatum Kunze & & 1 & & 7 & & 8 & 0.30 \\
\hline Chaetomium globosum Kunze & 23 & 14 & 6 & & 3 & 46 & 1.72 \\
\hline $\begin{array}{l}\text { Cladosporium cladosporioides (Fresen) } \\
\text { G. A. de Vries }\end{array}$ & & 1 & 13 & 1 & 12 & 27 & 1.01 \\
\hline Cladosporium herbarum (Pers.) Link & & & 1 & & & 1 & 0.04 \\
\hline Cladosporium sphaerospermum Penz. & & 4 & & & 9 & 13 & 0.49 \\
\hline $\begin{array}{l}\text { Clonostachys rosea f. rosea (Link) } \\
\text { Schroers, Samuels, Seifert et W. Gams }\end{array}$ & & 5 & & & & 5 & 0.19 \\
\hline Coleophoma empetri (Rostr.) Petr. & & 1 & 2 & & 6 & 9 & 0.34 \\
\hline $\begin{array}{l}\text { Davidiella macrocarpa Crous, K. Schub. } \\
\text { et U. Braun }\end{array}$ & & 7 & & 6 & & 13 & 0.49 \\
\hline Diplodia melaena Lév. & & & & & 3 & 3 & 0.11 \\
\hline Drechslera poae (Baudys) Shoemaker & & & 16 & & & 16 & 0.60 \\
\hline Epicoccum nigrum Link & 33 & 108 & 31 & 90 & 12 & 274 & 10,24 \\
\hline Fusarium culmorum (W. G. Sm.) Sacc. & 9 & 4 & 1 & & & 14 & 0.52 \\
\hline Fusarium oxysporum Schltdl. & & & & & 17 & 17 & 0.64 \\
\hline Fusarium poae (Peck) Wollenw. & 4 & 1 & 4 & 2 & 7 & 18 & 0.67 \\
\hline Fusarium sporotrichioides Sherb. & 9 & & & & 2 & 11 & 0.41 \\
\hline $\begin{array}{l}\text { Gibberella tricincta } \text { El-Gholl, McRitchie, } \\
\text { Schoult et Ridings }\end{array}$ & & & & 4 & 1 & 5 & 0.19 \\
\hline Humicola fuscoatra Traaen & 3 & 4 & & 5 & & 12 & 0.45 \\
\hline Humicola grisea Traaen var. grisea & 2 & & & 7 & & 9 & 0.34 \\
\hline $\begin{array}{l}\text { Ilyonectria radicicola (Gerlach et L. } \\
\text { Nilsson) Cheverri et C. G. Salgado }\end{array}$ & & & 3 & & 28 & 31 & 1.16 \\
\hline Isaria farinosa (Holmsk.) Fr. & 38 & 44 & 82 & 45 & 41 & 250 & 9.35 \\
\hline Khuskia oryzae H. J. Huds. & 8 & & & 3 & & 11 & 0.41 \\
\hline Mammaria echinobotryoides Ces. & & 1 & & 2 & & 3 & 0.11 \\
\hline Morenoina paludosa J. P. Ellis & & & 6 & & & 6 & 0.22 \\
\hline Mortierella alpina Peyronel & 11 & 4 & 19 & 1 & 10 & 45 & 1.68 \\
\hline Mortierella parvispora Linnem. & 2 & & & & 1 & 3 & 0.11 \\
\hline Mucor hiemalis Wehmer & & 1 & & 9 & 22 & 32 & 1.20 \\
\hline Mycosphaerella iridis (Auersw.) J. Schröt. & & & & 2 & & 2 & 0.07 \\
\hline Myrothecium cinctum (Corda) Sacc. & & 10 & & & & 10 & 0.37 \\
\hline
\end{tabular}


Table1- cont.

\begin{tabular}{|c|c|c|c|c|c|c|c|}
\hline Neottiospora caricina (Desm.) Höhnel & & & & 3 & & 3 & 0.11 \\
\hline Nowakowskiella elegans (Nowak.) Schröt. & 1 & & & & & 1 & 0.04 \\
\hline Paecilomyces variotii Bainier & & & & & 1 & 1 & 0.04 \\
\hline $\begin{array}{l}\text { Paraconiothyrium minitans (W. A. } \\
\text { Campb.) Verkley }\end{array}$ & & & 2 & & & 2 & 0.07 \\
\hline $\begin{array}{l}\text { Paraphaeosphaeria michotii (Westend.) } \\
\text { O. Erikss. }\end{array}$ & & & 1 & & & 1 & 0.04 \\
\hline $\begin{array}{l}\text { Paraphoma chrysanthemicola (Hollós) } \\
\text { Gruyter, Aveskamp et Varkley }\end{array}$ & & & 3 & & 2 & 5 & 0.19 \\
\hline Penicillium aurantiogriseum Dierckx & 16 & & 9 & 3 & 8 & 36 & 1.35 \\
\hline Penicillium citrinum Thom & & 6 & & & 2 & 8 & 0.30 \\
\hline Penicillium expansum Link & 19 & 34 & & 1 & 32 & 86 & 3.21 \\
\hline $\begin{array}{l}\text { Penicillium hirsutum var. hirsutum } \\
\text { Dierckx }\end{array}$ & 15 & & & 10 & 15 & 40 & 1.50 \\
\hline Penicillium lanosum Westling & & & & & 12 & 12 & 0.45 \\
\hline Penicillium verrucosum Dierckx & 12 & 19 & & 1 & 79 & 111 & 4.15 \\
\hline Penicillium waksmanii $\mathrm{K} . \mathrm{M}$. Zalessky & & 1 & & & 12 & 13 & 0.49 \\
\hline $\begin{array}{l}\text { Periconia typhicola } \text { E. W. Mason et M. B. } \\
\text { Ellis }\end{array}$ & & 2 & & & & 2 & 0.07 \\
\hline Pestalotiopsis sydowiana (Bres) B. Sutton & & & & & 1 & 1 & 0.04 \\
\hline Phaeosphaeria eustoma (Fuckel) L. Holm & & 1 & & & & 1 & 0.04 \\
\hline Phaeosphaeria juncina (Auersw.) L. Holm & & & 4 & & & 4 & 0.15 \\
\hline $\begin{array}{l}\text { Phaeosphaeria typharum (Desm.) L. } \\
\text { Holm }\end{array}$ & & 4 & & & & 4 & 0.15 \\
\hline $\begin{array}{l}\text { Phialophora cinerescens (Wollenw.) J. F. } \\
\text { H. Beyma }\end{array}$ & & & 10 & 2 & & 12 & 0.45 \\
\hline Phialophora cyclaminis J. F. H. Beyma & 3 & 5 & & 10 & 4 & 22 & 0.82 \\
\hline $\begin{array}{l}\text { Phoma leveillei Boerema et G. J. Bollen } \\
\text { var. leveillei }\end{array}$ & & 2 & 17 & & & 19 & 0.71 \\
\hline $\begin{array}{l}\text { Phoma medicaginis var. medicaginis } \\
\text { Malbr. et Roum. }\end{array}$ & 7 & 7 & 5 & 24 & & 43 & 1.61 \\
\hline $\begin{array}{l}\text { Phyllosticta pseudacori (Brunaud) } \\
\text { Allesch. }\end{array}$ & & & & 11 & & 11 & 0.41 \\
\hline Physalospora scirpi (Gutner) Arx & & & 6 & 5 & & 11 & 0.41 \\
\hline Phytophthora citricola Savada & & & & & 3 & 3 & 0.11 \\
\hline $\begin{array}{l}\text { Phytophthora undulata (H. E. Petersen) } \\
\text { M. W. Dick }\end{array}$ & & & & & 12 & 12 & 0.45 \\
\hline $\begin{array}{l}\text { Pleustomophora richardsiae (Nannf.) L. } \\
\text { Hostert, W. Gams et Crous }\end{array}$ & & 21 & 3 & 6 & 4 & 34 & 1.27 \\
\hline Rhizopus arrhizus A. Fisch. var. arrhizus & 10 & & & & & 10 & 0.37 \\
\hline Rhizopus stolonifer (Ehrenb.) Vuill. & 9 & 6 & 1 & 1 & & 17 & 0.64 \\
\hline Scopulariopsis koningii (Oudem.) Vuill. & & 1 & & & & 1 & 0.04 \\
\hline Septoriella junci (Desm.) B. Sutton & & 1 & 9 & & & 10 & 0.37 \\
\hline $\begin{array}{l}\text { Sordaria fimicola (Roberge et Desm.) Ces } \\
\text { et De Not. }\end{array}$ & 5 & 25 & 18 & 9 & 24 & 81 & 3.03 \\
\hline Talaromyces wortmannii C. R. Benj. & & & & & 7 & 7 & 0.26 \\
\hline $\begin{array}{l}\text { Thielavia terricola (J. G. Gilman et E. V. } \\
\text { Abbott) C. W. Emmons }\end{array}$ & & & & & 1 & 1 & 0.04 \\
\hline Trichoderma aureoviride Rifai & & & & & 16 & 16 & 0.60 \\
\hline Trichoderma harzianum Rifai & & 5 & 2 & & & 7 & 0.26 \\
\hline Trichoderma koningii Oudem. & & & & & 2 & 2 & 0.07 \\
\hline Trichoderma pseudokoningii Rifai & & & & & 14 & 14 & 0.52 \\
\hline Trichoderma viride Pers. & & & & & 8 & 8 & 0.30 \\
\hline Trichothecium roseum (Pers.) Link & & 3 & & 2 & & 5 & 0.19 \\
\hline Ulocladium botrytis Preuss & & 2 & & & & 2 & 0.07 \\
\hline Umbelopsis isabellina (Oudem.) W. Gams & 2 & 3 & 5 & 9 & 15 & 34 & 1.27 \\
\hline Umbelopsis nana (Linnem.) Arx & & & & & 4 & 4 & 0.15 \\
\hline Volutella arundinis Desm. & & & 7 & & & 7 & 0.26 \\
\hline Total & 565 & 577 & 430 & $\mathbf{5 3 0}$ & 573 & 2675 & 100.00 \\
\hline
\end{tabular}


happened. The most numerous species in the community of isolated fungi were: $A$. alternata, $P$. verrucosum, $I$. farinosa, $P$. expansum and $I$. radicicola.

In two ponds $P h$. citricola and Ph. undulata were isolated from white water lily tissues.

The symptoms on rhizomes, petioles and leaf blades pointed to an occurrence of a disease determined as a black rot on rhizomes.

\section{DISCUSSION}

A comparison of results of mycobiota isolation from phyllosphere of plants which are the fixed components of the analyzed ponds and information about the occurrence of diseases on their aboveground and underground organs (Westcott 1971; Van der Aa 1978; Sutton 1980; Ellis, Ellis 1987; Helberg 1998; Wagner 2000; Kowalik, Krasny 2009; Mazurkiewicz-Zapałowicz, Grajewski 2010), revealed the most serious pathogen threat from the polyphagous, such as: A. alternata, $B$. cinerea, $E$. nigrum, $S$. fimicola. These fungi, most numerously isolated by the end of vegetation period colonized plant tissues causing necrosis.

The fungi constantly accompanying pond plants included also those from Mortierella and Umbelopsis genera, identified as hydrophilous (Domsch et al. 1980) and fungi from Aspergillus, Penicillium, Isaria, and Phialophora genera existing in many ecological niches (Kowalik, Maik 2010; Kowalik 2011b; Kowalik, Cwynar 2011).

Slightly less numerous Cladosporium spp. isolated from the phyllosphere are regarded as causes of leaf spot disease, necroses and disturbances in many plants growth, not only in ponds (Westcott 1971; Van der Aa 1978; Pląskowska 2010; Kowalik 2011b).

A fact of settling the petioles and leaf blades by Fusarium spp. is noticeable in the presented investigations. These fungi, especially F. culmorum, F. poae and F. sporotrichioides, which beside $A$. alternata, $A$. niger f. niger, $P$. aurantiogriseum,$P$. hirsutum var. hirsutum, and $P$. verrucosum are counted to toxicogenous ones which intensify necrotization process considerably contributing to fast destruction of plant tissues (Płażek 2011; Chełkowski 2012).

Fungi from Trichoderma genus, which are well known for their antagonism towards pathogenic fungi from Fusarium and Ilyonectria genera, were relatively little numerous on the plant tissues (except for white water lily).

Intensified occurrence of necrotrophs from Alternaria, Sordaria, Epicoccum, Chaetomium, Mucor and Rhizopus genera was noticed by the end of vegetation period, (in October), which confirms their ability to develop in dead tissues of the diseased plants.

Biodiversity of mycobiota in plant phyllosphere is evidenced by isolation of incidental saprotrophs which may develop both on live and dead tissue. Arthrinium, Boeremia, Diplodia, Mammaria, Nowakowskiella, Paraconiothyrium, Scopulariopsis, Thielavia, Ulocladium and other fungi only occasionally present on diseased shoots and leaves may be also counted to this group. 
Isolating from water plants the monophagous, which are strict parasites infesting calamus and soft rush in rush communities, Adamska 2005; MazurkiewiczZapałowicz et al. 2006; Mazurkiewicz-Zapałowicz, Grajewski 2010) and wild sedge, testifies their expansiveness and proves that they sporulate both on wild plants and ornamental cultivars (Czerniawska, Adamska 2009).

In ponds particular attention should be paid to hazard provided by Phytophthora, because chromistan fungi which belong to these genera commonly colonize perennial plants, dwarf shrubs, coniferous and deciduous plants in their natural environment, whereas water is the agent spreading propagule (Orlikowski 2006). The hazard has been confirmed by isolation of $P h$. citricola and $P h$. undulata from while water lily plants.

It should be surmised that the composition of mycobiota settling the phylosphere of plants depended on plant physiological properties and active substance content (ethereal oils, alkaloids, phytoncides and dyes), therefore the least number of fungi existed on calamus and soft rush. The role of fungi accompanying calamus vegetation and reducing the content of active substance were described by MazurkiewiczZapałowicz and Grajewski (2010).

While comparing the frequency of diseases occurrence on pond plants, it was noticed that while water lily and common cattail plants were the most frequently infested, which confirmed previous reports (Kowalik, Krasny 2009).

Assessing the healthiness of all plants planted in ponds it should be emphasized that it was satisfactory, which does not change the fact that visible leaf spot diseases and necroses on leaves and shoots do not improve aesthetic values of a pond, on the contrary, they greatly diminish them.

\section{CONCLUSIONS}

1. Dominance of mycobiota of Alternaria, Botrytis, Epicoccum, Fusarium, Isaria, and Penicillium genera in the phyllosphere of pond plants: white water lily, yellow iris, common cattail, soft rush and calamus results from their common occurrence in the environment, ability for fast spreading on plants growing in close vicinity, abilities for facultative parasitism and considerable reproductive potential.

2. It was stated that mycobiota of Botrytis, Ilyonectria, Fusarium, Phialophora, Pleustomophora, Phoma and Phytophthora accompanying the plants in a pond during vegetation season caused diverse discolourings and necroses on leaves and shoots.

3. Intensified tissue necrotization process on all plants in ponds occurred by the end of vegetation process and was connected with the frequency of occurrence in the phylosphere of necrotrophs of Alternaria, Sordaria, Epicoccum, Chaetomium, Mucor and Rhizopus genera.

4. While causing necroses, phyllosphere mycobiota of pond plants contributed to a destruction of tissues, which resulted in a diminishing of aesthetic values of ponds. 


\section{REFERENCES}

Adamska I. 2005. Fungal species new in Poland on Carex and Juncus. Acta Mycol. 40: 19-24.

Batko A. 1975. Zarys Hydromikologii. PWN.

Booth C. 1971. The genus Fusarium. CMI, Kew, Surrey, England.

Chełkowski J. 2012. Mikotoksyny, grzyby toksynotwórcze i mikotoksykozy. www.cropnet.pl/ mycotoxin: 1-100. [dostęp 18.01.2012].

Czerniawska B., Adamska I. 2009. Grzyby pasożytnicze występujące na turzycach. Prog. Plant Protection/ Post. Ochr. Roślin 49 (1): 187-190.

Domsch K.H., Gams W., Anderson T.H. 1980. Compendium of Soil Fungi. Acad. Press. London, New York, Toronto, Sydney, San Francisco.

Ellis M. B., Ellis J.P. 1987. Microfungi of Land Plants. Croom Helm. London, Sydney.

Helberg T. 1998. Ogrody Wodne. Delta W-Z. Warszawa.

Ho H.H. 1981. Synoptic keys to the species of Phytophthora. Mycologia 73: 705-714.

Kowalik M. 2011a. Fungi associated with plants calamus Acorus calamus L. during the vegetation season. Phytopathologia 60: 29-33.

Kowalik M. 2011b. Grzyby towarzyszące roślinom pałki szerokolistnej Typha latifolia L. w okresie wegetacji. Prog. Plant Protection/Post. Ochr. Roślin 51 (1): 269-273.

Kowalik M. 2012. Fungi and chromistan fungi associated with plants white water lily Nympaea alba L. during the vegetation season. Acta Scientarum Polonorum, seria Hortorum Cultus (in print).

Kowalik M., Cwynar A. 2011. Grzyby towarzyszące roślinom situ rozpierzchłego Juncus effusus L. w okresie wegetacji. Prog. Plant Protection/Post. Ochr. Roślin 51 (2): 652-655.

Kowalik M., Krasny M. 2009. Fungi occurring on garden pond plants. Phytopathologia 51: 21-26.

Kowalik M., Maik M. 2010. Grzyby w fylosferze irysa żółtego Iris pseudoacorus L. Prog. Plant Protection/ Post. Ochr. Roślin 50 (1): 218-221.

Mazurkiewicz-Zapałowicz K., Grajewski J. 2010. Grzyby fyllosfery Acorus calamus L. - cennej rośliny leczniczej. Prog. Plant Protection/Post. Ochr. Roślin 50 (1): 236-239.

Mazurkiewicz-Zapałowicz K., Wróbel M., Silicki A., Wolska M. 2006. Studies on phytopathogenic and saprotrophic fungi in rush association of Lake Glinno (NW Poland). Acta Mycol. 41(1): 125-138.

Orlikowski L.B. 2006. Relationship between source of water used for plant sprinkling and occurrence of Phytophthora shoot rot and tip blight in container ornamental nurseries. J. Plant Prot. Res. 46: 163-168.

Pląskowska E. (ed.). 2010. Miejskie Tereny Zielone - zagrożenia. UWP. Wrocław: 1-165.

Płażek A. 2011. Patofizjologia roślin. Wydawnictwo Uniwersytetu Rolniczego w Krakowie, Kraków.

Ramirez C. 1982. Manual and Atlas of the Penicillia. Elsevier Biomedical Press. Amsterdam, New York, Oxford.

Sivenesan A. 1984. The Bitunicate Ascomycetes and their Anamorphs. J. Cramer, Vaduz.

Sutton B.C. 1980. The Coelomycetes - Fungi Imperfecti with Pycnidia, Acervuli and Stromata. CMI, Kew, Surrey.

Van der Aa H.A. 1978. A leaf spot disease of Nymphaea alba L. in the Netherlands. E. J. Plant Pathology 84: $109-115$.

Wagner A. 2000. Fungi isolated from leaves of different Iris spp. Rocz. AR Poznań CCCXXI, Ogrodn. 30: $165-169$.

Westcott C.1971. Plant Disease Handbook. Van Nostrand Reinhold Co. New York, Cincinnati, Toronto, London, Melbourne. 
Fyllosferowe mykobiota roślin oczek wodnych

\section{Streszczenie}

W badaniach terenowych i laboratoryjnych przeprowadzonych w latach 2006, 2008-2010, w dwudziestu oczkach wodnych usytuowanych na terenie Małopolski i Podkarpacia określono stan zdrowotny: tataraku zwyczajnego Acorus calamus L., pałki szerokolistnej Typha latifolia L., situ rozpierzchłego Juncus effusus L., irysa żółtego Iris pseudoacorus L. i grzybienia białego Nymphaea alba L. Mykobiota bytujące w fyllosferze roślin powodowały różnorakie przebarwienia i nekrozy.

$\mathrm{Z}$ porażonych tkanek roślin wyodrębniono 2675 kolonii mykobiota, należących do 88 gatunków. W zbiorowisku wyodrębnionych mykobiota dominowały: Alternaria alternata, Epicoccum nigrum i Isaria farinosa. Mniej licznie izolowano grzyby z rodzajów: Aspergillus, Botrytis, Chaetomium, Cladosporium, Fusarium, Ilyonectria, Mortierella, Mucor, Penicillium, Phialophora, Phoma, Pleustomophora, Sordaria, Trichoderma i Umbelopsis.

Fyllosferowe mykobiota roślin oczek wodnych powodując nekrozy przyczyniały się do destrukcji tkanek, co skutkowało obniżeniem walorów dekoracyjnych oczek wodnych. 